\title{
PENERAPAN METODE STUDENT TEAM ACHIEVEMENT DIVISION UNTUK MENINGKATKAN MOTIVASI BELAJAR DAN PRESTASI BELAJAR PKN SISWA
}

\section{APPLICATION OF STUDENT TEAM ACHIEVEMENT DIVISION METHOD TO IMPROVE STUDY MOTIVATION AND PKN LEARNING}

\author{
ANI MIYASIH TRISNAWATI \\ SMA Negeri 6 Pandeglang \\ Dinas Pendidikan Dan Kebudayaan
}

\begin{abstract}
Abstrak
Dari hasil penelitian tindakan kelas dengan menggunakan metode pembelajaran kooperatif tipe STAD dapat meningkatkan motvasi belajar PKN siswa dikelas dilihat adanya peningkatan, dimana pada pertemuan pertama $50 \%$ siswa yang keaktifan dan kerjasama masih kurang baik berkurang menjadi $10 \%$ pada pertemuan ketiga. Pada pertemuan pertama $50 \%$ siswa yang keaktifan dan kerjasama baik dan sangat baik mengalami peningkatan menjadi menjadi $90 \%$ pada pertemuan ketiga. Dari hasil peningkatan tersebut maka dapat dikatakan bahwa penerapan metode pembelajaran kooperatif tipe STAD sudah dpt dikatakan meningkat motivasi belajar. Hal ini menunjukan bahwa terjadi peningkatan terhadap motivasi belajar siswa pada mata pelajaran PKN. Dengan menggunakan metode STAD dapat meningkatkan prestasi belajar. Peningkatan prestasi belajar dapat dilihat dari adanya peningkatan nilai rata-rata yang diperoleh siswa pada pra tindakan dan setelah tindakan. Dilihat nilai rata-rata Siklus 1 adalah 88 sedangkan nilai rata-rata sebelum tindakan adalah 73. Sehingga kemampuan prestasi belajar mengalami peningkatan dan tercapainya taraf ketuntasan belajar, yaitu 75. Hal ini menunjukan bahwa terjadi peningkatan terhadap prestasi belajar siswa pada mata pelajaran PKN.
\end{abstract}

Kata kunci: Metode Student Team Achievement Division

\begin{abstract}
From the results of classroom action research using the STAD type cooperative learning method can increase students' PKN learning motivation in the classroom seen an increase, where at the first meeting $50 \%$ of students who were active and cooperation was not good reduced to $10 \%$ at the third meeting. At the first meeting $50 \%$ of students whose activeness and cooperation was good and very good had increased to $90 \%$ at the third meeting. From the results of these improvements it can be said that the application of the STAD type of cooperative learning methods can be said to increase learning motivation. This shows that there is an increase in student motivation in PKN subjects. Using the STAD method can improve learning achievement. Improved learning achievement can be seen from an increase in the average value obtained by students in the pre-action and after the action. Judging by the average value of Cycle 1 is 88 while the average value before the action is 73. This shows that an increase in student achievement in the subject of Civic Education.
\end{abstract}

Keywords: Student Team Achievement Division Method 


\section{PENDAHULUAN}

Pendidikan adalah usaha sadar dan terencana untuk mewujudkan suasana belajar dan proses pembelajaran agar peserta didik secara aktif mengembangkan potensi dirinya untuk memiliki kekuatan spiritual keagamaan, pendidikan diri, kepribadian, kecerdasan, akhlak mulia, serta keterampilan yang diperlukan dirinya, masyarakat, bangsa dan negara. Tujuan pendidikan nasional adalah untuk berkembangnya potensi peserta didik agar menjadi manusia yang beriman dan bertaqwa kepada Tuhan Yang Maha Esa, berakhlak mulia, sehat, berilmu, cakap, kreatif, mandiri dan menjadi warga negara yang demokrasi serta bertanggung jawab (UU No. 20 tahun 2003 Pasal 3).

Setelah mengadakan prasurvai di tempat yang akan peneliti lakukan yaitu di SMAN Negeri 6 Pandeglang. Berdasarkan informasi dan wawancara terhadap guru pada saat kegiatan belajar mengajar kelas selalu ribut, siswa kurang berani bertanya pada guru kalau ada materi pelajaran yang belum dipahami. Anak cenderung tidak begitu tertarik dengan mata pelajaran Pendidikan Kewarganegaraan karena hanya hafalan, sehingga menyebabkan rendahnya motivasi belajar. Prestasi belajar juga siswa masih rendah, karena masih ada beberapa siswa yang belum mencapai taraf ketuntasan belajar, yaitu minimal 75 sehingga masih perlu perbaikan.

Melihat permasalahan di atas, terdapat suatu gambaran bahwa akar penyebab masalah bermuara pada strategi pembelajaran yang kurang mampu membangkitkan motivasi belajar siswa untuk belajar. Hal ini dapat mempengaruhi motivasi siswa dalam proses pembelajaran, maka akan berpengaruh pada prestasi belajar siswa nantinya. Hal-hal lain yang mempengaruhi siswa dalam menengkap pelajaran adalah ketika di kelas guru mengajar jarang menggunakan metode yang dapat menarik siswa dalam belajar dan metode yang digunakan guru sedikit. Keadaan ini dapat ditanggulangi jika guru menyajikan materi pembelajaran dengan metode yang bervariasi pada setiap pengajarannya. Jadi dapat disimpulkan bahwa dengan menggunakan metode pembelajaran yang bervariasi diharapkan dapat meningkatkan motivasi belajar siswa dan kemudian akan berpengaruh pada prestasi belajar siswa.

Alternatif penelitian tindakan kelas sebagai upaya untuk pemecahan masalah dengan mengatasi kebekuan dan kebuntuan pengajaran Pendidikan Kewarganegaraan yang kurang diminati 
siswa. Dengan memeberikan metode pembelajaran Student Teams pembelajaran yang tepat untuk Achievement Division (STAD) pada melibatkan siswa secara totalitas adalah kelas $X$ di SMAN 6 Pandeglang. Untuk pembelajara kooperatif tipe STAD mengetahui seberapa tinggi merupakan pendekatan yang baik peningkatan prestasi belajar siswa untukmeningkatkan motivasi belajar dan dengan penggunaan metode prestasi belajar siswa dalam mata pembelajaran Student Teams pelajaran Pendidikan Kewarganegaraan. Dalam STAD siswa bekerja bersama-sama untuk mempelajari dan menyelesaikan suatu masalah. Tujuan dari pembelajaran STAD ini dapat memotivasi siswa supaya saling mendukung dan membantu satu sama lain dalam menguasai kemampuan yang diajarkan oleh guru.

\section{Berdasarkan pembatasan} masalah di atas, maka rumusan masalah dari penelitian ini adalah : Seberapa tinggi peningkatan motivasi belajar siswa dengan penggunaan metode pembelajaran Student Teams Achievement Division (STAD) pada kelas $X$ di SMAN 6 Pandeglang? Seberapa tinggi peningkatan prestasi belajar siswa dengan penggunaan metode pembelajaran Student Teams Achievement Division (STAD) pada kelas $X$ di SMAN 6 Pandeglang?

Tujuan yang ingin dicapai dari penelitian ini adalah: Untuk mengetahui seberapa tinggi peningkatan motivasi belajar siswa dengan penggunaan

\section{KAJIAN TEORIK}

Metode adalah cara di dalam fungsinya merupakan alat untuk mencapai suatu tujuan, sedangkan metode pembelajaran adalah cara guru. Pengertian itu diperkuat lagi oleh Winarno Surakhmad (1982:96) bahwa metode pembelajaran adalah cara yang di dalam fungsinya merupakan alat untuk mencapai tujuan pengajaran.

Kriteria yang digunakan dalam memilih metode pembelajaran menurut I.L Pasaribu\& B. Simanjuntak (1980:41) antara lain :

1. Sesuai dengan tujuan pelajaran

2. Sesuai dengan waktu, tempat dan alat-alat yang tersedia dengan tugas guru

3. Sesuai dengan jenis kegiatankegiatan yang tercakup dalam pelajaran

4. Menarik bagi siswa

5. Maksudnya dipahami oleh siswa

6. Sesuai dengan kecakapan guru 
STAD merupakan salah satu metode pembeajaran kooperatif yang paling sederhana, dan merupakan model yang paling baik untuk permulaan bagi para guru yang baru menggunakan pendekatan kooperatif. STAD terdiri dari lima komponen utama, yaitu:

Materi di dalam STAD pertamatama diperkenalkan dalam presentasi di dalam kelas. Ini merupakan pengajaran langsung yang dipimpin oleh guru, tetapi bisa juga memasukan presentasi audiovisual. Dengan cara ini, para siswa akan menyadari bahwa mereka harus benar-benar member perhatian penuh selama presentasi kelas.

Sebelum memulai pembelajaran STAD akan lebih baik jika memulai dengan satu atau lebih latihan pembentukan tim.sekedar unutk memebrikan kesempatan kepada anggota tim untuk melakukan sesuatu yang mengasyikan dan untuk mengenal satu sama lain. Misalnya, tim boleh saja diberikan kesempatan untuk menciptakan logo tim, baner, lagu atau syair.(Slavin:2008:143-151)

STAD terdiri dari atas sebuah siklus instruksi kegiatan reguler, sebagai berikut:

1. Mengajar, menyampaikan pelajaran

2. Belajar Tim, para siswa bekerja dengan lembat kegiatan dalam tim mereka untuk menguasai materi
3. Tes, para siswa mengerjakan kuiskuis individual

4. Rekognisi tim, skor tim dihitung berdasarkan skor kemajuan yang dibuat tiap anggota tim, dan sertifikat individual, lembar berita kelas, atau papan bulletin yang merekognisi tim dengan skor tertinggi.

(Slavin:2008:151-152)

\section{METODE PENELITIAN}

Penelitian ini merupakan Penelitian Tindakan Kelas (PTK). Subjek dalam penelitian ini adalah siswa Kelas X A SMA Negeri 6 Teknik pengambilan sampel menggunakan sampel bertujuan atau puposive sample. Sumber data dalam penelitian ini adalah siswa kelas $X$ yang terdiri dari 4 kelas dengan jumlah total 144 siswa. Sedangkan Sampel penelitian ini diambil satu kelas yaitu kelas $X \quad A$ yang merupakan kelas yang paling pasif, prestasi belajar rendah dan juga motivasi belajaranya kurang hal ini berdasarkan hasil pengamatan dan informasi dari guru kolaborator.

\section{HASIL PENELITIAN DAN \\ PEMBAHASAN}

Pada pertemuan kedua ini adalah melanjutkan kegiatan pada pertemuan sebelumnya dan memberikan bantuan kepada siswa 
yang merasa belum paham terhadap materi pembelajaran. Untuk kesalahankesalahan yang bersifat umum, misalnya mengenai siswa yang belum bisa bekerja secara kelompok-kelompok kecil guru menjelaskan kembali secara klasikal. Peneliti bersama kolaborator mengamati perilaku siswa, reaksi, metode, dan suasana pembelajaran, serta peran guru dalam menerapkan model pembelajaran STAD.

Dari hasil pengamatan yang dilakukan kemudian dibandingkan dengan hasil wawancara kepada siswa yang dilakukan termasuk diskusi yang dilakukan bersama dengan kolaborator dan berdasarkan kuis yang ada dapat disimpulkan bahwa motivasi belajar dan prestasi belajar siswa meningkat . Mereka merasakan senang dan antusias dalam mengikuti pelajaran Pendidikan Kewarganegaraan melalui tahapan yang ada dalam pembelajaran dengan metode STAD.

Hal senada juga diutarkan oleh guru, bahwa model pembelajaran ini merupakan model pembelajaran yang tepat untuk meningkatkan motivasi dan prestasi belajar siswa. Guru pun merasa tidak kesulitan dalam menerapkan pembelajaran STAD dalam materi menampilkan sikap positif terhadap sistem hukum dan peradilan nasional.
Hasil penelitian menunjukkan adanya peningkatan kualitas pembelajaran yang dilihat dari meningkatnya motivasi dan prestasi belajar siswa dalam kegiatan pembelajaran. Hal tersebut diketahui dari perubahan ke arah yang lebih baik yang terjadi pada saat kegiatan pembelajaran. Motivasi dan Prestasi belajar siswa dalam kegiatan pembelajaran mengalami peningkatan. Kegiatan pembelajaran tidak lagi didominasi oleh guru. Dari segi jumlah siswa yang antusias dalam aktif dan kerjasama dalam kerja kelompok setelah diadakanya tindakan mengalami peningkatan. Selain itu nilai ulangan siswa juga mengalami peningkatan setelah adanya tindakan.

Untuk meningkatkan motivasi siswa dalam pembelajaran dan prestasi belajar siswa peneliti bersama guru kolaborator memberikan perlakuan pada siswa. Pada akhir tindakan kualitas kegiatan pembelajaran juga mengalami kemajuan yang dilihat dari meningkatnya motivasi dan prestasi belajar siswa Berdasarkan hasil tersebut di atas selanjutnya dapat disimpulkan bahwa implementasi tindakan berupa penggunaan pembelajaran STAD dapat meningkatkan motivasi dan prestasi belajar siswa. Keberhasilan dapat dilihat dari proses siswa kerjasama kelompok 
dan keaktifannya dalam kelompok, dan prestai belajar dapat dilihat dari peningkatan hasil tes. Penggunaan model pembelajaran STAD dapat membantu siswa untuk meningkatkan motivasi dan prestasi belajarnya. Hal ini dikarenakan siswa belajar secara langsung dengan belajar secara kelompok untuk menguasai materi sendiri bukan karena mendengarkan ceramah guru.

\section{SIMPULAN}

Berdasarkan hasil penelitian tindakan kelas yang telah dilakasanakan dalam aktifitas belajar siswa pada mata pelajaran PKn kelas X A di SMA Negeri 6 Pandeglang dapat ditarik kesimpulan sebagai berikut:

1. Dengan menggunakan metode pembelajaran kooperatif tipe STAD dapat meningkatkan motvasi belajar PKN siswa dikelas dilihat adanya peningkatan, dimana pada pertemuan pertama $50 \%$ siswa yang keaktifan dan kerjasama masih kurang baik berkurang menjadi 10\% pada pertemuan ketiga. Pada pertemuan pertama $50 \%$ siswa yang keaktifan dan kerjasama baik dan sangat baik mengalami peningkatan menjadi menjadi $90 \%$ pada pertemuan ketiga. Dari hasil peningkatan tersebut maka dapat dikatakan bahwa penerapan metode pembelajaran kooperatif tipe STAD sudah dpt dikatakan meningkat motivasi belajar. Hal ini menunjukan bahwa terjadi peningkatan terhadap motivasi belajar siswa pada mata pelajaran PKN.

2. Dengan menggunakan metode STAD dapat meningkatkan prestasi belajar. Peningkatan prestasi belajar dapat dilihat dari adanya peningkatan nilai rata-rata yang diperoleh siswa pada pra tindakan dan setelah tindakan. Dilihat nilai rata-rata Siklus 1 adalah 88 sedangkan nilai rata-rata sebelum tindakan adalah 73. Sehingga kemampuan prestasi belajar mengalami peningkatan dan tercapainya taraf ketuntasan belajar, yaitu 75 . Hal ini menunjukan bahwa terjadi peningkatan terhadap prestasi belajar siswa pada mata pelajaran $\mathrm{PKN}$.

\section{DAFTAR PUSTAKA}

Abdul Azis Wahab. New Paradigm and Curriculum Design for New Indonesian Civic Education. Bandung: Remaja Rosdakarya. 2000

Anita Lie. Cooperative Learning, mempraktikan cooperative 
learning di ruangruang kelas. Moleong, Lexy J. Metodologi Penelitian Jakarta: Grasindo. 2004 Kualitatif. Bandung: PT Remaja Cholisin. Materi Pokok IImu Rosdakarya. 2000 Kewarganegaraan - Pendidikan Ngalim Purwanto. Psikologi Pendidikan. Kewarganegaraan. Jakarta: PT. Remaja Rosdakarya: Universitas Terbuka. 2000

Bandung. 2007

Konsolidasi Demokrasi Melalui Pengembangan Karakter Kewarganegaraan. Dalam Jurnal Civics Volume 1 Nomor 1 Juni 2004. Yogyakarta: Fakultas IImu Sosial dan Ekonomi. 2004

Dasim Budimansyah. Pembelajaran Pendidikan Kewarganegaraan Berbasis Portofolio. Dalam Jurnal Civics Volume 3 Nomor 1 Juni 2006. Yogyakarta: Fakultas IImu Sosial dan Ekonomi UNY. 2006

Depdiknas. Peraturan Menteri Pendidikan Nasional No 22 Tahun 2006 tentang Standar Isi. Dari situs http://www.gurupkn.wordpress.co m. (diakses tanggal 4 januari 2012). 2006

Dimyati dan Mudjiono. Belajar dan Pembelajaran. Jakarta: Pusat Perbukuan \& Rineka Cipta. 2006

Ika Retno Bintari. "Konsep PKn" www.uny.ac.id/akademik

Diakses pada tanggal 22 Oktoberber 2008. 2007

Pasaribu I.L dan B. Simandjuntak. Proses Belajar Mengajar. Jakarta : Tarsito Bandung. 1980

Sardiman AM. Interaksi dan Motifasi Belajar Mengajar. Yogyakarta: Rajawali. 1992 - Interaksi dan Motifasi Belajar Mengajar. PT. Raja Grafindo Persada : Jakarta. 2001 Slavin E Robert. Cooperative Learning. Bandung : Nusa Media. 2008

Sri Rumini dkk. Psikologi Pendidikan. Yogyakarta: UPP IKIP Yogyakarta. 1991

Suharsimi Arikunto. Prosedur Penelitian: Suatu Pendekatan Praktek edisi Revisi IV. Jakarta: Rineka Cipta. 2002

Tim Peneliti. Standar Operasional Prosedur (SOP) Pengembangan Sistem Pengujian Berbasis Kemampuan Dasar Siswa Sekolah Menengah Umum Mata Pelajaran Pendidikan Kewarganegaraan. Yogyakarta: Program Pasca Sarjana UNY. 2002 
Tim Penyusun. Inovasi ICT dan

Multimedia SD Muh CC

2007/2008. Dari situs

http://www.jogjabelajar.org/sdmu

hconcat/mod/forum/discuss.

(diakses tanggal 10 Januari 2008). 2006

Tim Penyusun. Undang-Undang Republik Indonesia Nomor 14 Tahun 2004 tentang Guru dan Dosen serta Undang-undang Republik Indonesia No 20 Tahun 2003 tentang Sistem Pendidikan

Nasional. Bandung: Citra Umbara. 2002

Warsono. Peranan Pendidikan

Kewarganegaraan sebagai Pilar

Pendidikan Hak Asasi Manusia.

Dalam Jurnal Civics Volume 3

Nomor 1 Juni 2006. Yogyakarta:

Fakultas IImu Sosial dan

Ekonomi UNY. 2006

Winarno Surakhmad. Mengenal Metode

Pengajaran di Sekolah dan

Pendekatan Baru dalam Proses

Belajar Mengajar. Yogyakarta :

Amarta Buku. 1982

Kewarganegaraan

Pendidikan

Persekolahan: Standar Isi Dan Pembelajarannya. . Dalam Jurnal Civics Volume 3 Nomor 1 Juni 2006. Yogyakarta: Fakultas IImu Sosial dan Ekonomi UNY. 2006 